\title{
Killing Competitive Authoritarianism Softly: The 2019 Local Elections in Turkey
}

\section{Berk Esen \& Sebnem Gumuscu}

To cite this article: Berk Esen \& Sebnem Gumuscu (2019) Killing Competitive Authoritarianism Softly: The 2019 Local Elections in Turkey, South European Society and Politics, 24:3, 317-342, DOI: $10.1080 / 13608746.2019 .1691318$

To link to this article: https://doi.org/10.1080/13608746.2019.1691318

曲 Published online: 18 Nov 2019.

Submit your article to this journal $\pi$

Џ Article views: 1318

Q View related articles $\sqsubset$

View Crossmark data $\nearrow$ 


\title{
Killing Competitive Authoritarianism Softly: The 2019 Local Elections in Turkey
}

\author{
Berk Esen and Sebnem Gumuscu
}

\begin{abstract}
On 31 March 2019 Turkish voters ended the Islamist local governance in the country's largest cities after 25 years and handed the ruling AKP its most serious electoral defeat since its rise to power in 2002. The article explores the electoral strategies of major parties in the local election, offers a comparative analysis of the results, and discusses postelection developments, including the rerun in Istanbul. The election and its aftermath reaffirmed the competitive authoritarian nature of the regime, as the governing bloc enjoyed an uneven playing field, while the opposition had to meet a higher electoral bar than the incumbents to win. The economic crisis, growing discontent with the government's policies, and effective coordination of opposition parties facilitated this outcome.
\end{abstract}

\section{KEYWORDS}

Municipal elections; provincial elections; repeat election; AKP; CHP; Erdoğan

Turkish voters headed to the polls on 31 March 2019 and ended the long-lasting hold of the ruling AKP (Adalet ve Kalkınma Partisi, Justice and Development Party) on local government in the country's major provinces. This defeat came after 25 years of Islamist control and handed the most serious electoral defeat to the ruling party since its rise to power in 2002. Although it gained the plurality of the votes in the country, AKP lost municipal governments in major metropolitan areas which had provided the party with extensive resources for patronage. Indeed, in Istanbul and Ankara this control dated back to 1994, when AKP's predecessor, RP (Refah Partisi - Welfare Party) won these metropolitan municipalities for the first time. Those cadres had remained in power ever since, even though RP split and gave birth to AKP in 2001.

The election results affirmed that AKP's support base is weakening in metropolitan districts and shifting to peripheral areas and to poor neighbourhoods in urban centres, while the opposition is making advances in Turkey's most populous and economically advanced provinces. As the main opposition party, the secular-centrist CHP (Cumhuriyet Halk Partisi - Republican People's Party) benefitted the most from AKP's decline and managed to consolidate the opposition vote. The decision of the centre-right IYI Parti (Good Party) and pro-Kurdish Peoples' Democracy Party (Halkların Demokrasi Partisi - HDP) voters to support 
CHP candidates in metropolitan races facilitated this electoral win (Konda 2019a). The remaining opposition parties, however, registered limited success. While IYI Parti failed to win a single province, the Kurdish political movement mostly stood its ground in its strongholds in the southeast, albeit losing a few key provinces to AKP.

The local elections demonstrated that the political regime in Turkey is still competitive authoritarian (Esen \& Gumuscu 2016) and has not yet turned into full authoritarianism, as some scholars claim (Tuğal 2016; Çalışkan 2018). Both the campaign cycle and electoral results confirm this conclusion. As in the previous elections held since 2014 (Sayarı 2016; Kemahlıoglu 2015; Esen \& Gumuscu 2017b), the ruling bloc led by AKP dominated the media and the public space and took advantage of its disproportionate access to both public and private sources. Such advantages tilted the playing field in favour of candidates from AKP and its junior partner, the Turkish nationalist MHP (Milliyetçi Hareket Partisi - Nationalist Action Party), without precluding a win for opposition candidates.

At the same time, despite the uneven playing field, the opposition won against all odds in several provinces across the country. In provinces with lower political and economic stakes, AKP accommodated greater competition and conceded its losses; in others, where stakes were much higher, AKP resorted to differing degrees of authoritarianism to reverse the electoral results and defeat its rivals. The latter included Istanbul, the economic bastion of the country, as well as Kurdish populated provinces. In the latter, the ruling AKP could appoint state officials to purge elected mayors with impunity, whereas in Istanbul its decision to force a re-run mayoral election led to the party's defeat a second time and reinforced competitive elements of the regime.

The local elections thus affirmed several key features of the competitive authoritarian regime in Turkey. First, AKP could lose elections despite the tilted playing field. The results also showcased that when an economic crisis and growing discontent with government's policies accompanies effective coordination among opposition parties, a competitive authoritarian regime may suffer major electoral losses. Secondly, the authoritarian elements of the regime remained intact as the party mobilised politicised state institutions to reverse outcomes. For instance, the YSK (Yüksek Seçim Kurulu - Supreme Electoral Council), which is the public body in charge of overseeing the elections, played a key role in this process by making a series of legally questionable decisions in favour of AKP. Third, to win, the opposition had to meet a higher electoral bar than the incumbent party. Even then, their electoral victory was not certain, since the government abused its power to replace electorally elected mayors with its own members or state employees soon after the election in several Kurdish-populated provinces. In short, while the regime remained competitive authoritarian at the broader level, there emerged differing levels of competitiveness and authoritarianism across the country. ${ }^{1}$ 
In the rest of the article we offer a comprehensive analysis of the 2019 local elections and their long-term implications for Turkish politics. We first introduce several key developments that set the political stage in the lead up to the local elections. Next, we describe the different strategies employed by the two main electoral coalitions as well as HDP and Islamist SP (Saadet Partisi - Felicity Party) during the campaign and focus on several contests in major metropolitan areas, such as in Istanbul and Ankara. We note the highly divisive rhetoric adopted by the ruling bloc composed of AKP and MHP that continued to enjoy an uneven playing field against the opposition. In the following section, we analyse the election results and continue with a brief discussion of key post-election developments, including the rerun election in Istanbul. Finally, we conclude with a general discussion of how this result may shape regime dynamics in Turkey in the near future.

\section{Towards the local elections}

The March 2019 mayoral race was the seventh time Turkish voters went to the polls since the last local elections of March 2014. In between there had been presidential elections in 2014, two general elections in 2015, a referendum on regime change in 2017 and both presidential and parliamentary elections in 2018. In 2019, political parties were competing to capture mayoral seats in Turkey's 81 provinces (il) - 30 of which are designated as metropolitan municipalities (büyükşehir) - as well as its 919 districts and 397 sub-districts. ${ }^{2}$ The electoral stakes were quite high since local governments have traditionally offered an array of patronage sources for political parties and generated significant competition among them (Sayarı 2014; Bayraktar \& Altan 2013). AKP is no exception. As Eligür (2010) and Ark-Yıldırım (2017) argue, municipalities formed the origins of AKP and the primary sources of its popularity. As Kemahlioğlu and Özdemir (2018) show, its provision of public services and expenditures through local governments, increased the party's vote share at the national level. Municipal governments also enabled the ruling party's uneven access to public and private resources, essential for its electoral hegemony. In fact, the party channelled greater aid to its municipal governments prior to elections in competitive races (Kemahlioğlu \& Özdemir 2018).

Since 2002 AKP has relied on elections to establish its hegemony in the country both at the national and local levels (Sayarı 2016; Kalaycıoğlu 2015; Gumuscu 2013). The party won the March 2014 local elections and the August 2014 presidential elections by a landslide. This electoral hegemony permitted the party to redesign the political system, undermine horizontal accountability, tilt the playing field in its favour, and control local and national resources for clientelist purposes (Esen \& Gumuscu 2016).

Since 2015 the party's electoral success has been somewhat mixed. In the June 2015 national elections, AKP won the plurality of the votes and seats in the 
parliament yet lost its parliamentary majority for the first time since the 2002 general elections. Instead of forming a coalition government, Erdoğan pushed for snap elections in November 2015. In between two elections, the security situation in the country rapidly deteriorated as the government and the Kurdish insurgency engaged in a new cycle of armed conflict and AKP cracked down on the Kurdish movement (Ercan 2019). At the same time, ISIS increased its attacks on Turkish soil, thereby evoking fear among the people. Such fears secured a parliamentary majority for the party in November 2015, yet AKP failed to fulfil its promise of stability in the ensuing months.

Only a year later, a junta within the Turkish armed forces attempted to overthrow the government (Esen \& Gumuscu 2017a). Although the Turkish democracy did not fall prey to a military intervention, it could not escape Erdoğan's increasing control over the state apparatus and political system. Soon after the coup attempt, President Erdoğan instated emergency law and subsequently pushed for a set of constitutional amendments to create an executive presidential system (Esen \& Gumuscu 2018b). In the meantime, he continued to rule by decree, effectively ending the parliamentary system. MHP's support in the process proved crucial. This support laid the foundation for an AKP-MHP alliance, while at the same time triggering an internal conflict within the party, as we will discuss below. In 2017, in a much-contested referendum, the Turkish people voted - albeit by a small margin - in favour of an executive presidency with weak checks and balances (Esen \& Gumuscu 2017b). Turkey remained under emergency law until the June 2018 elections, when Erdoğan was elected the first president under the new system. Since then, he has continued to rule by decree to circumvent the parliament where his party lacks a majority.

As a corollary to these developments, democracy continued to backslide in the country, reinforcing AKP's competitive authoritarianism (Esen \& Gumuscu 2016), as each election proved to be less free and fair than the preceding one. The circumstances of the 2019 elections, however, differed from the previous elections in two key respects. First, while the government still enjoyed the uneven playing field, the impending economic crisis in the country weakened the AKP government. The main source of the party's popularity has been its ability to deliver economic stability and growth to all income groups in the country and particularistic benefits to its clients among the business as well as the urban poor, especially at the local level (Yörük 2012; Esen \& Gumuscu 2018a). The economic crisis made it harder for AKP to deliver on its material promises. For the opposition, the mayoral race was therefore a valuable opportunity to challenge both the government's authoritarian measures and President Erdoğan's increasing control over the state apparatus, at least at the local level. Meanwhile, AKP had to sustain its dominance in local governments, which have served as a major venue for clientelist distribution, providing the AKP machine with unequalled material and human resources. 
Secondly, the electoral system had changed in 2018 , only a few months prior to the presidential and parliamentary elections. The new law primarily allowed political parties to form electoral alliances. This effectively lifted the national threshold for parties in electoral coalitions, since they would gain seats in proportion to their votes if their alliance surpassed 10 percent. For local elections, which rested on the winner takes all logic, parties could join forces behind a joint candidate and pool their resources to win municipal governments.

Political parties, including new actors such as the centre right iYi Parti, established by former MHP members under Meral Akşener's leadership in 2017, took advantage of this opportunity for the first time in the 2018 parliamentary elections. ${ }^{3}$ AKP formed an alliance with MHP to secure its dominance and instate the Turkish-Islamic synthesis as the government ideology, while CHP joined forces with IYI, centre-right DP (Demokrat Parti - Democrat Party) and Islamist SP (Saadet Partisi - Felicity Party) to form a democratic bloc against AKP's authoritarian rule. The pro-Kurdish HDP campaigned alone, as the polarising and nationalist rhetoric of the ruling bloc suffocated Kurdish political activism and drove a wedge within the opposition.

In the local elections in 2019, all major parties retained these alliances. The ruling AKP and MHP preserved their electoral coalition - Cumhur Ittifakı (People Alliance, PA) - across much of the country, though the two parties nominated separate candidates in some provinces and districts. Likewise, CHP and IYI Parti maintained the Millet Ittifakı (Nation Alliance, NA), this time without the support of SP and DP, both of which ran independent campaigns. As in the 2018 parliamentary elections, HDP was excluded from both coalitions and vilified by the AKPMHP bloc throughout the campaign. With its two former co-chairs and several MPs in jail, the HDP organisation entered the campaign greatly weakened. While focusing its limited resources on the party's strongholds in heavily Kurdishpopulated areas, HDP also lent support to the Nation's Alliance in several metropolitan races instead of fielding its own candidates.

As a result of these developments, three factors in particular led to AKP's declining vote share primarily in major cities. First, the economic crisis hit the country in 2018 with significant effects on different constituencies. Second, the opposition crafted an electoral strategy with centrist candidates who could supersede Erdoğan's polarisation strategy. Third, AKP's alliance with the nationalist MHP and its embrace of ultra-nationalist discourse alienated Kurdish voters. Finally, the discontent among the Turkish people vis-à-vis the government's policies towards Syrian refugees has increased in conjunction with the impending economic crisis in the country. While the ruling bloc retained a lead in the absolute number of votes, many disillusioned voters decided not to turn out to vote as a protest (Konda 2019a).

Hitherto, AKP's political dominance has mostly rested on good economic performance (Çarkoğlu 2008; Öniş 2015; Gidengil \& Karakoç 2016). The economic crisis, however, starting in the Summer of 2018 with depreciation of the 
Turkish lira, resulted in a recession in February 2019, thereby increasing the government's vulnerability. Industrial production declined steadily beginning in late 2017, and overall unemployment hit 14.1 percent in March 2019 while youth unemployment reached 25.2 percent (Yeni Şafak 2019). Possibly more disconcerting to the electorate has been the rising inflation rate, which reached 19.7 percent by March 2019. Food inflation, in particular, remained high with 29.8 percent (BloombergHT 2019). To ameliorate the effects of the economic crisis on its urban constituency, the AKP municipalities began to sell subsidised fresh produce in poor neighbourhoods, yet, this measure's impact was limited.

In the midst of this economic decline, the resources which the AKP government allocated to Syrian refugees may have stirred discontent among different segments of society. As Fisunoğlu and Sert (2019) find, the refugees have already had a negative, albeit insignificant, impact on AKP's vote share in districts with concentrated refugee population. It is safe to claim that combined with the effects of the economic crisis this discontent increased. In 2016 a survey documented that those AKP supporters who foresaw an economic crisis in the country held unfavourable views of Syrian refugees. 79 percent of such respondents claimed that Syrian refugees created unemployment in the country, while 74 percent agreed that Turkey should not accept any more refugees (Konda 2016). We suspect that this impact has only increased with the rising severity of the economic crisis and reduced AKP's popularity with voters.

Another key feature of AKP's political strategy has been polarisation (McCoy, Rahman \& Somer 2018; Aydın-Düzgit \& Balta 2018). This strategy reduced the likelihood of the AKP electorate voting for the opposition even when they were discontented with government policies (Erdoğan 2016). Yet, the new electoral law, introduced in 2018, weakened the effects of AKP's strategy and unintentionally strengthened the opposition bloc while undermining AKP's position within the ruling coalition. CHP, in particular, has emerged as a focal point within the opposition bloc due to its ability to speak to other parties from different ideological backgrounds. At the same time, electoral alliances provided discontented AKP voters with an alternative choice of voting for MHP candidates without betraying their support for Erdoğan.

Finally, the government's crackdown on the Kurdish movement led to significant electoral losses. Since HDP's strong electoral showing in the 2015 June elections, Erdoğan's government had targeted Kurdish activism. With the formation of the AKP-MHP alliance, Erdoğan further suffocated Kurdish political mobilisation. Indeed, several leaders of the Kurdish movement, including Selahattin Demirtaş, remain imprisoned at the time of writing. Erdoğan's turn to nationalism in recent years alienated Kurdish voters and pushed the HDP leadership to throw its support behind CHP candidates in several metropolitan areas. This critical support gave CHP the margin of victory against the progovernment candidates in several close races. 


\section{The campaign: to polarise or not to polarise}

\section{People's alliance}

AKP and MHP formed the People's Alliance (PA) as a conservative nationalist bloc prior to the 2018 presidential elections. The two parties rallied around the 'Turkish-Islamic synthesis', an ideology based on the primacy of Turkish nationalism and conservative Islamic values with a hawkish stance vis-à-vis the Kurdish movement, the secular opposition and the left. ${ }^{4}$ Although this alliance allowed Erdoğan to win the presidency in June 2018, it was not immediately clear if the AKP-MHP alliance would hold up this time. After days of long negotiations, the two parties finally agreed to run joint candidates in 51 provinces, with separate nominees in the remaining 29 (Hürriyet 2019). Of those 51 provinces, AKP nominated its candidates on behalf of the alliance in 27 metropolitan areas (including Istanbul, Ankara, and Izmir) and 17 provinces. MHP, the junior partner in the bloc, ended up with nominees in three metropolitan areas (Mersin, Adana, Manisa - southern and inland cities) and four provinces (Iğdır, Kars, Kırklareli, Osmaniye).

Throughout the election cycle, the People's Alliance mobilised both national and local resources on the campaign trail. Still, AKP's hegemony over the political system did not preclude internal conflict, as indicated by Erdoğan's decision in 2018 to replace his party's elected mayors with appointees in Istanbul, Ankara, Bursa, Balıkesir, and Niğde. Signalling his total control of the ruling party, Erdoğan also hand-picked the nominees for the March 2019 elections. In so doing, Erdoğan preferred quite experienced names for three major cities to display the significance of local elections to his constituency. The former prime minister and Speaker of Parliament, Binali Yıldırım, ran in Istanbul; former minister of urban development Mehmet Özhaseki competed in Ankara, and former minister of the economy Nihat Zeybekçi joined the race in Izmir. All three figures were Erdoğan loyalists but lacked strong local roots in the cities where they were nominated.

Despite the fact that this was a local election, President Erdoğan made a strong showing throughout the campaign cycle and refused to delegate the campaign to these high-profile nominees. He held 102 rallies in 59 cities in 50 days (Sabah 2019). As the public face of the campaign, Erdoğan's picture was placed next to those of the nominees on all party banners across the country (AK Parti 2019a). Moreover, he gave eight televised interviews to 14 different stations to discuss AKP's local governance. In one of these interviews, quite tellingly, he showed up on the national television along with all the nominees of Istanbul's 39 districts. The seating arrangement, with Erdoğan in the centre across the moderators, and with the 39 nominees lined up in silence in the far corner of the room, attested to the Erdoğanisation of local politics.

AKP picked an emotional slogan, Gönül Belediyeciliği (local governance from the heart) for its campaign (AKP 2019b). Its electoral manifesto, announced by 
Erdoğan, promised a different urban development model than the party had followed in the past 15 years. Ironically, the manifesto - which read like a selfcriticism - promised more transparency, openness, civic engagement in local decision-making processes, as well as greater commitment to environmental protection and conservation of cultural heritage and natural resources. On the other hand, the party frequently highlighted the services they had provided in the past to convince the voters that it was the most experienced and qualified in local governance. These two strategies undermined the coherence of AKP's campaign.

MHP's leader Devlet Bahçeli was much less visible, although he too served as the face of his party's campaign. In contrast to Erdoğan, in the entire campaign Bahçeli held only 12 rallies - some jointly with AKP - and two closed meetings. The party adopted two slogans for its campaign: 'Beka için milli karar, Cumhur için istikrar' (a national decision for survival; stability for the people) and 'Türkiye ehline emanet' (Turkey is entrusted to the qualified). While the first slogan evoked fears of instability and security concerns; the second implied that MHP (and AKP) were the most qualified parties. MHP's campaign strategy depended much less on local issues than it did on the security threats the nation faced and the resulting need for the People's Alliance as its saviour. The party leaders often stated that a candidate's party identity mattered more than his/her solutions to local issues. As such, both AKP and MHP attributed national and existential significance to a local election.

Not surprisingly, polarisation and delegitimisation of the opposition marked the PA's campaign strategy. With reference to local politics, Erdoğan frequently associated the main opposition party, CHP, with trash, mud, and pot-holes signs of incompetence in municipalities. At the same time, the PA signalled to its constituency that this was no ordinary local election. The two allies capitalised on polarisation and fear on the campaign trail, echoing far-right populist movements in Europe. In particular, the alliance mobilised identity politics through the use of nationalist and Islamic themes. The PA nominees unequivocally depicted the mayoral race as a matter of life and death, and claimed that Turkey's national security was at stake ('beka meselesi') because the opposition parties - CHP, IYI Parti, SP, and HDP - had collaborated with the 'enemies' of the nation, namely the Kurdish separatist organisation (PKK) and the Gülenists (FETO). ${ }^{5}$ For both Erdoğan and Bahçeli, this was an alliance of contempt and shame (illet and zillet ittifakı). Bahçeli called the local elections the last exit before the precipice:

The 31 March elections offer a critical choice between truth and lies and between patriots and terrorists ... How would the shameful alliance, which walks on a dark path towards the unknown and guides the nation towards disasters, account for its partnership with the Kurdish separatists and traitors? The Turkish nation would never accept and forget such treason (NTV 2019a). 
The PA, they claimed, would defend the nation's interests and fight against its enemies. Hence, they raised the stakes of the local elections in order to mobilise and consolidate their base.

Islamism marked the final cornerstone of the PA's campaign strategy. Accordingly, the government claimed that it defended not only the interests of the nation, but also served as the guardian of the Muslim world. They maintained that the enemies of Islam desired to undermine PA's power in a revanchist fashion because it had defended Muslims' interests. During a rally, Erdoğan displayed the video recording of the violent attack in New Zealand against Muslims and urged his supporters to defeat the enemies of Islam and the Turkish nation at the polls on the election day. Their aim, the alliance suggested, was to silence the call to prayer, take down the Turkish flag, and return Turkey to its pre-Islamic past. And they would succeed through their allies in Turkey, i.e. the opposition. Unlike other parties, the PA claimed, they trusted in God alone and served with faithful cadres (Takvim 2019).

\section{Nation's alliance}

In the opposition camp, during the 2018 campaign, CHP had led the Millet Ittifakı (Nation's Alliance, NA) composed of several right-wing parties, namely iYi Parti, Saadet Partisi and Demokrat Parti. IYi Parti was established by dissident MHP elites, who broke ranks with Bahçeli after his decision to support Erdoğan's plan to establish an executive-presidential system. In contrast to the People's Alliance, the NA lacked a coherent ideology and instead rallied around a common commitment to parliamentary democracy (Esen \& Gumuscu 2017b).

The opposition entered the campaign in a demoralised state, having lost the 2018 presidential elections from the first round and failed to win a parliamentary majority. The poor electoral showing had exposed the opposition leaders to intra-party challenges and brought the viability of the NA into question (Yeniçağ 2018; T24 2018). Some figures within iYi Parti and SP attributed their parties' poor results to their alliance with CHP, for they believed the main opposition party's secularist position reduced their appeal amongst the conservative-nationalist constituency. Eventually, the SP would leave the alliance to contest the elections alone in all provinces. Meanwhile, the CHP and IYi Parti leaders re-formed the Nation's Alliance and nominated joint candidates in 22 metropolitan areas and 27 provinces, while running separate candidates in the remaining 32 (CNNTürk 2019).

As the main opposition party, CHP entered the campaign cycle amidst a recent leadership contest waged by the party's presidential candidate Muharrem Ince in the June 2018 election (Esen \& Yardimci-Geyikçi 2019). Immediately after the general elections, İnce called for a party convention but failed to draw sufficient support from the party delegates. Although Kemal Kılıçdaroğlu managed to retain his post as the party chairman, the CHP base was split between him and İnce in the lead up to 
the 2019 local elections. Thus, the intra-party squabbles generated widespread disillusionment amongst CHP voters. Against this backdrop, Kılıçdaroğlu's decision to nominate several centrist candidates for key races encountered significant intraparty resistance and was only resolved after a major standoff in the Party Council (GazeteDuvar 2019). Kılıçdaroğlu's strategy was to nominate candidates with wider popular appeal and also support from the IYi Parti leadership. In Istanbul, Izmir, Ankara, Bursa, Adana, and Antalya, CHP nominated experienced district mayors such as Ekrem İmamoğlu and Mansur Yavaş, who were seen as successful by large segments of the electorate and could thus supersede the prevailing polarisation.

Kılıçdaroğlu, unlike Erdoğan, ran an active but not very visible campaign, which left room for the party's candidates. Throughout the campaign he visited nearly 30 cities across the country but focused especially on metropolitan areas such as Istanbul (which he visited seven times), Ankara, Izmir, Bursa and Antalya. In seven provinces (Burdur, Aydın, Balıkesir, Denizli, Manisa, Kocaeli, Bursa, and Antalya) where the secular nationalist vote was strong, Kılıçdaroğlu campaigned together with IYi Parti chairwoman Akşener to solidify his party's alliance with iYi Parti (Karar 2019a).

In sharp contrast to the People's Alliance's national security discourse, CHP emphasised local issues that had resonance with the electorate. While the PA capitalised on polarisation, CHP avoided divisive remarks to appeal to progovernment voters with concrete proposals. The CHP leadership adopted a discourse of hope as pronounced in its slogan: 'the end of March is spring' (martın sonu bahar). The party summarised its official strategy in a booklet titled 'Book of Radical Love' (radikal sevgi kitabı). ${ }^{6}$ Along these lines, party leaders asked its members to embrace pro-government voters, show empathy for their concerns, and appeal to them through messages of love (Euronews 2019a). They were to avoid hubris, sarcasm, and haste, while making sure to focus on local issues and problems.

The party's candidates in major cities stuck to this overall strategy, while also using their personal stories to reach out to voters. For instance, coming from a conservative family from the Black sea region of northern Turkey, the party's Istanbul mayoral candidate İmamoğlu was not a typical CHP politician. As such, he demonstrated his piety by praying in public and using a moralistic discourse in his speeches. When Tayyip Erdoğan tried to incite anger by exploiting the attack against Muslims in New Zealand, Imamoğlu prayed for the victims citing Quranic verses in Arabic at the mosque. ${ }^{7}$ These symbolic moves reassured some conservative voters who opposed the CHP and at the same time raised İmamoğlu's popularity and visibility. Similarly, as a former mayor from the MHP ranks, Yavaş could appeal both to centrist and nationalist voters in Ankara.

Similar to CHP, IYi Parti entered the campaign with a challenging task. After the split from MHP, the party encountered difficulty in consolidating the nationalist voters, and it faced internal rifts. Those coming from an ultranationalist background were uneasy with Akşener's efforts to pull the party to 
the centre, while centrist newcomers were disappointed with the party's failure to emerge as a moderate alternative to AKP. The party lacked strong cadres, resources, and a clear political direction. Partly due to these concerns, the IYi Parti leadership stayed within the Nation's Alliance for the local elections but did not wage a strong campaign.

During the alliance talks, IYi Parti left major metropolitan areas such as Istanbul, Izmir, Ankara, Antalya, Adana, and Mersin to CHP, but insisted on getting several Anatolian provinces where conservative voters are overrepresented. In exchange for the support it received in 26 provinces (including 10 major metropolitan areas), CHP supported IYI Parti's candidates in 23 provinces (CNNTürk 2019). iYI's strategy was to consolidate its base by winning the local government in these areas to gain credibility, visibility, and access to resources. In some of these provinces, the party leadership went with former MHP mayors who supported Akşener during the split while in other areas they nominated fresh faces. Akşener's party also sought to capture the local government in those provinces where it had performed well in the 2018 parliamentary elections, such as Antalya and Izmir.

Given her popularity and name-recognition, IYi Parti's campaign revolved around Meral Akşener, who held rallies in 21 provinces and 55 districts. Her rallies drew a strong crowd especially in the Anatolian provinces hit hard by the economic crisis. In her speeches, Akşener targeted both Erdoğan and Bahçeli to promote her party as the right-wing alternative to the ruling bloc. She adopted a critical tone especially against Erdoğan, while dismissing Bahçeli as the small coalition partner. At the centre of IYi Parti's campaign was the mismanagement of the Turkish economy by Erdoğan's son-in-law Minister Berat Albayrak, declining opportunities in agriculture and tourism, and the Syrian refugee crisis that left a huge burden on border towns and major metropolitan areas. The party accused the AKP government of corruption and nepotism, despite having initially come to power with the promise of clean government. As such, IYI's campaign platform relied heavily on centre-right themes such as the provision of services and meritocratic appointments in civil service. Its manifesto highlighted people-centred local governance (insan merkezli sosyal belediyecilik) and it sought to occupy the middle ground by emphasising local issues with a conservative tone without a direct challenge to republican values (IYi Parti 2019).

Unlike CHP which refrained from alienating HDP voters, the IYI Parti leadership denied any involvement with the HDP under the umbrella of the NA. During the campaign, Akşener even pulled out her party's candidate in Iğdır in favour of the MHP candidate so as to not split the anti-HDP vote in a city sharply divided between Azeri Turks and Kurds (Yeniçağ 2019). Her aim was to reinforce her nationalist credentials in the face of the allegations raised by the AKP-MHP bloc regarding a treasonous alliance among the opposition parties. 


\section{The non-aligned opposition of Kurdish and Islamist origins}

The electoral stakes were also quite high for HDP for a number of reasons. First, since its strong showing in the June 2015 general election, HDP has been criticised for its equivocal position towards the PKK, and it had difficulties in chartering a stable political position in the midst of escalating violence in the southeast. Moreover, the AKP government cracked down on HDP, and the party's organisation in numerous districts had ceased to exist as a result. The leadership was not spared; several parliamentary deputies, including the party's charismatic ex-chairman, Selahattin Demirtaş, and numerous mayors elected under the party's list remained in prison, while party officials were systematically harassed by the security personnel (Martin 2018).

The party viewed the local elections as an opportunity to recover its strength. Furthermore, the Kurdish political movement historically attached greater significance to local government for a number of reasons (i.e. high electoral threshold, regional concentration of the Kurdish people, low electoral strength at the national level). Indeed, many of the party's political elite had begun their careers as mayors or local activists. This trend slightly changed in 2014 when the newly formed HDP established political coalitions with minor left-wing parties and adopted a Turkey-wide strategy, shifting from a regional focus to the national level (Grigoriadis 2016). The AKP government's repressive measures against the Kurdish movement, however, compelled HDP to return to local politics as a way of political survival.

Not surprisingly, HDP's strategy in the 2019 local elections differed starkly from its campaign in 2014, when it had nominated candidates primarily in western districts to reach out to non-Kurdish voters, while supporting its sister party, namely DBP (Demokratik Bölgeler Partisi - Democratic Regions Party), in the heavily Kurdish-populated southeast region. ${ }^{8}$ In the 2019 election campaign, however, HDP focused on recovering municipal governments in the southeast, where the AKP government had replaced DBP mayors with state appointees on the pretext that municipal resources had been used for terror activities (Martin 2018). Meanwhile, the HDP leadership decided not to nominate candidates in seven metropolitan municipalities and instead called on its supporters to vote against the PA - which many of its voters saw as support given to CHP. As the party co-Chair Sezai Temelli put it, HDP's strategy was 'Winning in Kurdistan, making AKP and MHP lose in the west' (Bianet 2019).

HDP spent the campaign on the defensive against both government attacks and biased media coverage. During the campaign, HDP activists were attacked, harassed, and detained on numerous occasions to weaken the party organisation, as had also been the case in the 2015 and 2018 general elections. Moreover, HDP candidates were given limited airtime and were generally excluded from media coverage as public and private television channels refused to run the party's official campaign ad (Bianet 2019). On occasional instances 
when HDP was included in news stories, the motivation was to distort the party's message in an attempt to persuade Turkish voters not to support the opposition.

Finally, the Islamist SP left the Nation's Alliance and ran an independent campaign with its own separate candidates in all provinces. Although it is a minor party in the Turkish political spectrum, SP remained highly critical of the AKP-MHP coalition throughout the campaign and aimed to build political bridges with secular parties to defeat AKP's polarising discourse around Islamic values and identity. The party's aim was to appeal to AKP's conservative constituency through a heavy emphasis on governmental corruption, injustice, and economic failures. The party promised clean politics, justice, and equitable economic growth and hoped to draw support from pious AKP voters who were disillusioned with their party's recent direction and poor public services.

\section{Election results: the decline of the People's Alliance and the rise of the opposition}

The 2019 local election was arguably the closest race which AKP had fought among the 11 elections it had contested since its establishment in 2001. In this section we discuss the results by way of two main comparisons. The first involves the contrast between the local elections in 2014 and 2019 to display the electoral shifts at the local level (See Figures 1 and 2 and Tables 1 and 4). The second entails an analysis of the vote shares of parties and alliances since the 2018 twin elections (see Tables 2 and 3).

\section{From 2014 to 2019: putting AKP's local election losses in perspective}

The People's Alliance (PA) received a majority (51.6 per cent) of the votes (YSK 2019) and AKP has remained the largest political party in the country. However, its vote share declined with respect to the 2014 local elections, and the party lost key municipalities which had been under the control of Islamists since 1994. Thus, many local governments in the economic centre of the country changed hands from AKP to CHP. By losing major provinces to its opponents, AKP was confined to the social and economic periphery at the local government. The fact that AKP had contested the 2014 local elections without any allies while in the 2019 local elections it had formed an alliance with MHP, makes the party's losses more noteworthy. Despite AKP and MHP joining forces, the opposition still managed to defeat the ruling coalition in many major provinces (see Figures 1 and 2). This success was largely the product of the electoral coalition forged by CHP and IYi Parti, which also received tactical support from HDP in the western provinces. Indeed, the uneven playing field and the government's repressive measures over recent years have encouraged opposition parties to overcome their ideological differences and run a coordinated campaign against the 
People's Alliance. The biggest beneficiary of this strategy was CHP whose candidates won mayoral races in five of the six most populous provinces, thanks to the opposition of IYI Parti and HDP to the increasingly authoritarian AKP.

In contrast to the previous local elections, shown in Figure 1, the March 2019 results produced a balanced electoral map between the ruling AKP and other political parties (see Figure 2). Overcoming its historical problem of electoral ghettoisation (Ciddi \& Esen 2014), CHP succeeded in broadening its appeal in large parts of the country. In addition to its traditional strongholds (Izmir, Aydin, Eskisehir and Edirne), CHP now controls the Aegean and Mediterranean coastline (Antalya, Adana, Mersin, and Hatay) and also runs municipal governments in both the northern (Sinop, Artvin, and Ardahan) and central Anatolia (Bolu, Bilecik, and Ankara) regions.

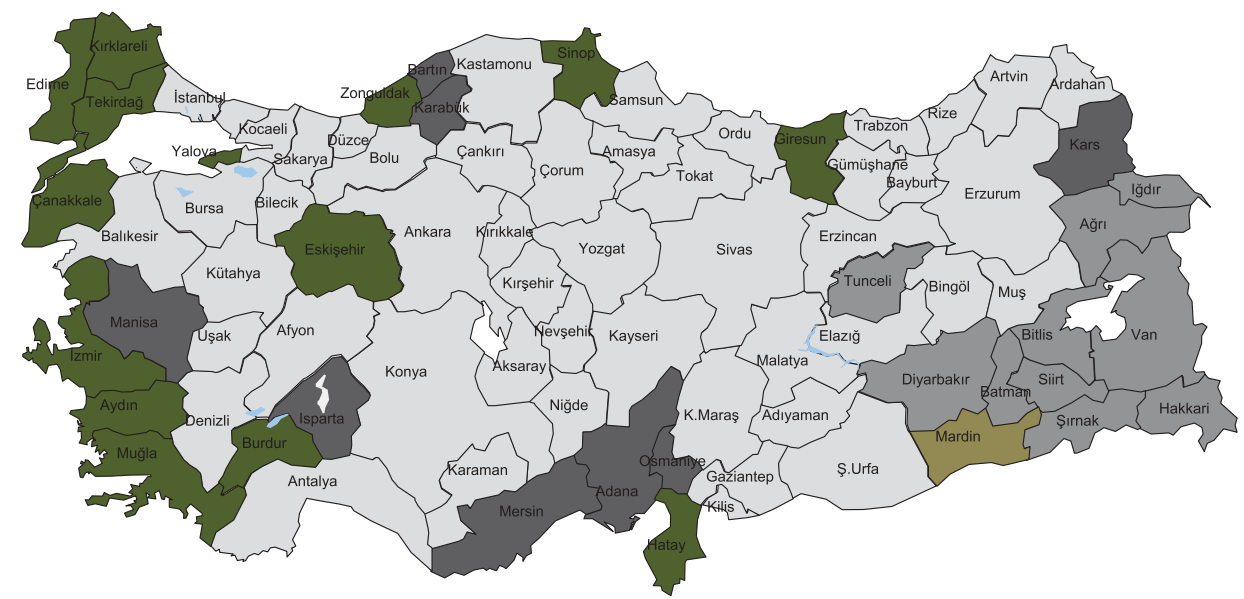

Figure 1. The 2014 local election results in Turkey by province.

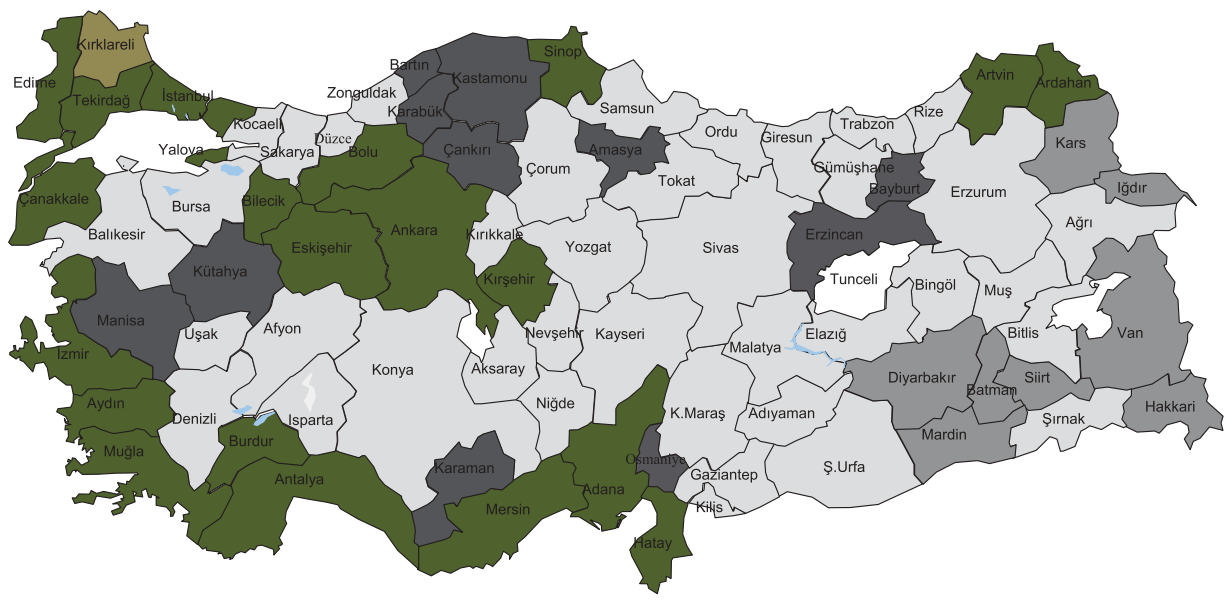

Figure 2. The 2019 local election results in Turkey by province. 
However, the party failed to win a single district in eastern and southeastern Anatolia, where HDP and AKP remain the only viable parties. Indeed, HDP retains its strong control over the heavily Kurdish populated provinces despite the strong government crackdown. The ruling party also faced an unlikely challenge from its partner MHP which contested elections with its own candidates in 27 provinces (BBC Türkçe 2019a). Relying on a nationalist campaign platform, MHP stole the support of many nationalist AKP voters and defeated its ally in nine conservative provinces of central Anatolia. In the end, each of these parties have eroded AKP's hegemony by defeating incumbent mayors of the ruling party in different parts of the country. The only exception was iYi Parti, which failed to win a mayoral race at the provincial level, albeit losing by small margins in Uşak, Balıkesir and Afyon.

In 2019, the People's Alliance won 16 metropolitan and 34 provincial municipalities, while the Nation's Alliance carried 11 metropolitan and 10 provincial municipalities (see Table 1). The ruling party now controls only 39 provinces in total (down from 48 out of 81), having lost seven to CHP and another three to MHP. Pro-Kurdish HDP, which was excluded from both alliances, won eight provinces in total (compared to ten in 2014) - all in Kurdish populated cities in Turkey's south-eastern region. Also, for the first time in Turkish history, TKP (Türkiye Komünist Partisi - Turkish Communist Party) won a provincial municipality in Tunceli in the east.

As Table 2 shows, the opposition has also broken the electoral hegemony of the AKP-MHP alliance in the country's largest cities in particular. In the 2014 local elections, AKP alone dominated the field in almost all of the major provinces while CHP won only in its secular stronghold Izmir, and MHP took Adana. This time around, even with MHP's support, AKP narrowly won in Bursa and carried only the culturally conservative provinces of Anatolia such as Konya, Kayseri, and Gaziantep. By contrast, CHP won in five out of the six most populous and economically vibrant provinces, taking Istanbul, Ankara, and Antalya from AKP, and Adana from MHP and holding onto its strongholds in Izmir and Eskişehir.

Table 1. Parties winning metropolitan and provincial municipalities in the 2014 and 2019 local elections in Turkey.

\begin{tabular}{|c|c|c|c|c|}
\hline & \multicolumn{2}{|c|}{ Metropolitan } & \multicolumn{2}{|c|}{ Provincial } \\
\hline & 2019 & 2014 & 2019 & 2014 \\
\hline AKP & 15 & 18 & 24 & 30 \\
\hline $\mathrm{CHP}$ & 11 & 6 & 10 & 8 \\
\hline BDP/HDP & 3 & 2 & 5 & 8 \\
\hline MHP & 1 & 3 & 10 & 5 \\
\hline TKP & & & 1 & \\
\hline Independent & & 1 & 1 & \\
\hline Total & 30 & 30 & 51 & 51 \\
\hline
\end{tabular}

Source: Compiled by authors using YSK election data (2019) 
Table 2. Vote share of electoral alliances in the 2019 local elections in Turkey: the largest provinces by population.

\begin{tabular}{lcc}
\hline & AKP-MHP & CHP-IYI \\
\hline İstanbul & 45.0 & 54.2 \\
Ankara & 47.1 & 50.9 \\
İzmir & 38.7 & 58.1 \\
Bursa & 49.6 & 47.0 \\
Antalya & 46.3 & 50.6 \\
Adana & 42.8 & 53.6 \\
Konya & 70.5 & 20.2 \\
Şanlıurfa & 60.8 & $*$ \\
Gaziantep & 54.0 & 16.4 \\
Kocaeli & 55.6 & 32.7 \\
Average & 51.0 & 42.7 \\
\hline
\end{tabular}

Source: Compiled by authors using YSK election data (2019)

* Saadet Party competed against AKP in Şanlıurfa and received 36.5 percent of the votes

Table 3. Parties' vote shares in the 2014 and 2019 local elections in Turkey.

\begin{tabular}{lcccccr}
\hline & \multicolumn{2}{c}{2019 Local elections } & & \multicolumn{3}{c}{ 2014 Local elections } \\
\cline { 2 - 3 } & AKP+MHP & CHP & & AKP & CHP & MHP \\
\hline İstanbu** & 48.5 & 48.8 & & 47.9 & 40.1 & 4.0 \\
Ankara & 47.1 & 50.9 & & 44.9 & 43.8 & 7.8 \\
İzmir & 38.7 & 58.1 & & 35.9 & 49.6 & 8.0 \\
Bursa & 49.6 & 47.0 & & 49.5 & 28.7 & 15.4 \\
Antalya & 46.3 & 50.6 & & 36.4 & 34.6 & 24.3 \\
Adana** & 42.8 & 53.6 & & 32.0 & 25.0 & 33.6 \\
\hline
\end{tabular}

Source: Compiled by authors using YSK election data (2019)

*Vote shares in the 31 March 2019

**Nation's alliance ran with AKP candidates in six major metropolitan areas, except Adana.

As Table 3 shows, the trend has been in favour of the opposition. Whereas in 2014 AKP dominated five of the six largest provinces, in 2019 it could prevail only in one with the support of MHP.

\section{AKP's declining electoral fortunes since 2015}

AKP's losses were not confined to the 2019 local elections. Indeed, the party has been haemorrhaging votes since the June 2015 elections, with the only exception being the snap elections in November 2015 (Öniş 2016). To halt this electoral decline, Erdoğan forged the alliance with MHP in 2016. But instead of consolidating the conservative nationalist constituency, it resulted in substantial numbers of MHP voters switching to the opposition camp with the establishment of iYi Parti. Between the 2018 general and 2019 local elections, the PA lost across the board, with the exception of Antalya and Izmir, where it registered limited gains with no impact on the outcome (see Table 4). In contrast, the opposition Nation's Alliance made significant electoral advances, receiving 37.6 percent of the votes nationwide (YSK 2019) and increasing its support in all major provinces (by more than 10 percentage points in Istanbul, Ankara, Bursa, and Adana). 
Table 4. The electoral decline of the People's Alliance and the rise of Nation's Alliance between 2018 and 2019: the largest provinces.

\begin{tabular}{lccccc}
\hline & \multicolumn{2}{c}{2019 Local elections } & & \multicolumn{2}{c}{2018 National elections } \\
\cline { 2 - 3 } \cline { 5 - 6 } & People's Alliance & Nation Alliance & & People's Alliance & Nation Alliance \\
\hline İstanbul & 45.0 & 54.2 & & 51.0 & 35.9 \\
Ankara & 47.1 & 50.9 & & 53.6 & 39.7 \\
İzmir & 38.7 & 58.1 & & 35.0 & 53.0 \\
Bursa & 49.6 & 47.0 & & 56.9 & 36.9 \\
Antalya & 46.3 & 50.6 & & 45.1 & 47.0 \\
Adana & 42.8 & 53.6 & & 46.5 & 39.3 \\
\hline
\end{tabular}

Source: Compiled by authors using YSK election data (2019)

CHP was the main winner of this election. Although its vote share has not dramatically increased, the party captured 21 provinces in 2019 (as opposed to 14 in 2014). Out of seven newly gained municipal governments, five are in metropolitan areas. This victory would give CHP not only a strong local base but also a platform to reach out to millions of voters who will now be governed by a CHP mayor. At a time when Erdoğan has managed to tighten his control over the state apparatus, CHP's control over municipal governments would allow the main opposition party to accumulate resources, promote its agenda, and appeal to new voters. Should these mayors succeed in addressing local problems, the party's voter base would grow along with the mayors' personal popularity. In contrast, IYi Parti did not stand to benefit greatly from the opposition's momentum. Overall, Akşener's party won mayoral races in 19 districts, most of which are located in coastal areas such as Aydin, İzmir, Çanakkale, and Antalya but did not score any victories at the provincial level.

The electoral results demonstrate a complicated picture for the pro-Kurdish HDP. Faced with organisational challenges and a government crackdown, the party experienced some decline in its vote share (4.2 percent). HDP's main aim in the 2019 elections was to reclaim more than 80 districts and provinces taken over by state-appointed administrators after 2016. While the HDP candidates managed to recapture most of these municipalities and to win in new provinces such as Kars, the party lost against AKP in Şırnak and Bitlis and against the Turkish Communist Party in Tunceli. Despite its limited advances in Kurdishpopulated regions, HDP still emerged as the decisive factor in swaying the outcome of the elections in those metropolitan municipalities in the west where it did not field candidates and the margin of victory was small.

The Islamist SP, after its departure from the Nation's Alliance, fielded candidates in all provinces across the country. It was the only party to do so. Its electoral success, however, remained quite modest. The party failed to win any provinces, despite coming second in conservative cities such as Şanlıurfa, Adıyaman, and Bitlis, and the northern province of Ordu. Still, SP managed to win nine districts mostly in south-eastern and eastern Turkey populated by conservative Kurds and in a conservative western province, Sakarya. 


\section{Post-election developments and implications for AKP's competitive authoritarianism}

AKP's surprising defeat in major provinces tested the regime's competitive features. The burning question on election night on 31 March was whether AKP would concede local power, particularly in metropolitan areas such as Istanbul and Ankara which had been governed by Islamists since 1994. Events ensuing over the next month affirmed the hybrid nature of the Turkish regime. The ruling party did not rig the elections or use force against its opponents, and instead conceded its losses with a few crucial exceptions, such as in İstanbul and the HDPdominated provinces. In an overwhelming majority of provinces, the winners took office without any legal obstruction. In close races, however, AKP utilised its public and private resources to seek an official recount of votes, a re-run, or an attempt to prevent winners from taking office. The politicised state institutions such as the Supreme Election Council YSK played a key role in this strategy, while the progovernment media sought to generate public support for it.

The İstanbul elections in particular created unprecedented contention. On election night, initially the ruling party claimed victory in Istanbul on the basis of results released by Anatolian Agency (Anadolu Ajansı), Turkey's semi-official news agency. However, the CHP candidate İmamoğlu contested these results in a series of press conferences throughout the night. As the official vote count continued, AKP declared its victory the next day on billboards all around İstanbul. And when the YSK finally announced the official results - 48.8 per cent for İmamoğlu and 48.5 per cent for Yıldırım - the ruling party started a long legal battle for a re-run.

AKP contested the vote count as soon as the YSK announced the official results by pressuring state institutions to secure a favourable outcome. It initially requested the recount of invalid votes (around 250,000), which the YSK accepted - even though in other instances, the council rejected opposition requests based on stronger evidence. When the difference between the two candidates dropped only slightly, AKP demanded a recount in all Istanbul districts. This time, the YSK rejected AKP's request since there was no evidence to justify a recount. So the government mobilised the police force to collect evidence of irregularities in voters' lists, to no avail. Finally, AKP contested the composition of the supervisory committees at the polling booths, which included both civil servants and non-civil servants. The party claimed that non-civil servants would presumably bias the results. ${ }^{9}$ On 6 May, the YSK ruled for a re-run in Istanbul, citing the irregular formation of local electoral committees as the reason.

The decision was clearly political, since the YSK itself had formed these committees months before the election and had received no formal objections prior to the polls. Moreover, the Council had already rejected iYi Parti's request to repeat the elections in Mustafakemalpaşa, a district in Anatolia, where electoral committees were formed in exactly the same manner as in istanbul (Independent Turkish 2019). The YSK's decision was also legally questionable 
since on election day, the polling station committees oversaw four different ballots - metropolitan municipality, provincial assembly, district municipality, neighbourhood head - but the YSK cancelled only the metropolitan race, keeping others intact. In the meantime, the Council rejected most of the opposition appeals for a recount elsewhere (possibly affecting the outcome in Bursa, Balıkesir, Muş and many other places).

The judges also denied recognition to seven elected HDP mayors soon after the election on the grounds that they had been purged from the civil service. This was a curious decision since these candidates had been approved by the YSK prior to the mayoral races and a number of purged civil servants were already serving as parliamentary deputies from CHP, HDP, and SP. Soon after the YSK's decision, the AKP nominees petitioned to take over these municipalities. The YSK handed them over to the AKP candidates, even though the latter had lost the popular vote.

\section{Re-run in Istanbul}

For AKP, Istanbul is of crucial political and economic importance. Not only did Erdoğan's political career launch in İstanbul when he was elected mayor in 1994, but it is also the economic heart of the country, generating nearly one third of Turkey's GDP. Over the course of 25 years since Erdoğan's mayoral election, the metropolitan municipality has turned into a conglomerate with 28 companies providing countless services to 17 million Istanbul residents and 24 billion Turkish Lira (TL) in annual revenues. At the same time, the metropolitan municipality generates rents worth billions of dollars through its control of all construction permits, land allocation, and realty valuation. Over the past quarter century, municipal authority in urban development has indeed allowed Erdoğan to establish close ties with construction companies and to build his own personal network of cronies (Esen \& Gumuscu 2018a). At the same time, AKP allocated parts of municipal revenues and resources to İslamic foundations with close ties to the government, whose boards of trustees are populated by Erdoğan's family and close associates. It is estimated that former AKP mayors donated 850 million Turkish liras in kind to these foundations (DW 2019).

Having created another chance to re-run the mayoral race in Istanbul, the AKP elite reoriented its campaign to eliminate factors that had caused its electoral defeat on 31 March. First, Erdoğan took the back seat and left more autonomy for Yıldırım to run his own campaign. Yıldırım's second campaign was more voter-friendly and reflected İmamoğlu's strategy of face-to-face interaction. He met with voters on house visits, at farmers' markets and on the streets, while Erdoğan refrained from making frequent campaign stops.

Furthermore, the government tried discrediting İmamoğlu to undermine his popularity and to provoke him into polemics to revive polarisation over identity politics. Pro-government media and social media trolls employed what many 
called black propaganda tools to discredit İmamoğlu as the ethnic and religious 'other'. Accordingly, they claimed that he was of Greek origin (Pontus) and therefore was neither Turkish nor Muslim (BBC Türkçe 2019b). AKP leaders and pro-government media suggested that İmamoğlu would end the Islamic era in İstanbul and restore its Greek Orthodox past. The PA's aim was to evoke fears among the conservative nationalist constituency and distance them from the opposition candidate, who had hoped to overcome such divisions through a positive discourse.

Despite this strategy of polarisation around ethnic and religious identities, the nationalist MHP rarely took part in the campaign for the re-run. The party's relative invisibility was not surprising though. In such a close race, the PA needed the support of pro-Kurdish HDP voters, who made up more than 10 per cent of the electorate in the 2018 parliamentary elections. To win back conservative Kurdish voters, the People's Alliance relied heavily on Islam and toned down its Turkish nationalist discourse. As part of this new strategy, Yıldırım visited Diyarbakır, the city with the second largest Kurdish population after Istanbul, and made a number of symbolic gestures, such as calling the region Kurdistan and greeting people in Kurdish during his visit. Only two days before the elections, the government allowed the release of a letter reportedly penned by Abdullah Öcalan - the founder of the PKK serving a life sentence in prison - calling on Kurdish voters to remain neutral in İstanbul's elections. Erdoğan went so far as to endorse the contents of the letter in a live interview, while Bahçeli indirectly suggested that Kurds should follow Öcalan's leadership instead of HDP (T24 2019).

Faced with the government onslaught, İmamoğlu sustained his initial strategy and organised local rallies in AKP strongholds to overcome polarisation in Turkish politics. Thanks to his focus on local issues and his suburban background, he gathered unprecedented crowds in neighbourhoods that are not traditional CHP strongholds. In response to AKP's innuendos that he was of Greek origin, İmamoğlu visited three key northern cities on the Black Sea during a public holiday when tens of thousands of Istanbul voters born in the area visited their hometowns. İmamoğlu's visit prompted a popular mobilisation that resonated also in İstanbul. Certainly, his efforts and disciplined ground operation increased his popularity. Yet, another key factor of his rising support was the fact that the people perceived him as the winner of the first election and did not find the YSK decision justified. While the Turkish electorate remained largely silent on the government's decision to purge HDP mayors in the eastern provinces, in Istanbul many pro-government voters (particularly from MHP) switched their support to İmamoğlu after the re-run decision (Konda 2019b).

İmamoğlu won the re-run on June 23 with 54.2 percent of the votes against Yıldırım's 44.9 per cent, ending 25 years of Islamist control in Istanbul. In an impressive result, İmamoğlu increased his vote share from the March election in all İstanbul's districts due to higher levels of support from other opposition 
parties, with HDP voters serving as a critical group (Konda 2019b). Yıldırım, in contrast, lost votes in all districts except two. A major factor in the opposition's victory in both the March and June rounds of the Istanbul elections was high voter mobilisation at the ballot box and beyond. In the case of the re-run, even though it was a holiday season during which schools were closed, 84.5 percent of Istanbul residents turned out to vote. More than 150,000 volunteers monitored the election and the counting process to prevent the ruling party from rigging the election outcome (Euronews 2019b). Such an extensive ground operation was crucial in defeating the competitive authoritarian regime in Turkey's most populous city (Gumuscu 2019).

\section{Conclusion}

Although this was a local election, the results will likely have major implications for the AKP regime's sustainability in the long run. Despite the personalisation of power under an executive presidential system, Erdoğan has failed to stabilise the new system and his party's defeat will increase the political risks at a time of economic recession in the country. By contrast, the opposition parties - particularly, CHP - secured a strong power base at the local level to counter AKP's control of political institutions. There now seems to be a growing consensus that the centralisation of power under Erdoğan's presidency resulted in a suboptimal outcome for AKP, including poor economic performance, intense party polarisation, and institutional atrophy in the state.

Obviously, Erdoğan is still a popular politician and wields enormous power and influence within the country. The 2019 local elections have challenged, but not ended, his rule. However, Erdoğan's strategy of consolidating the nationalist and conservative voters within the AKP-MHP coalition seems to have backfired. In most electoral districts, the government bloc obtained fewer votes than the AKP and MHP combined vote combined in both the November 2015 and June 2018 general elections. Erdoğan's increasingly nationalist discourse led many Kurdish voters to throw their support behind CHP candidates in major metropolitan areas. Indeed, CHP candidates won in various districts by drawing support from both Turkish and Kurdish nationalist voters in addition to their traditional base. Aside from Erdoğan and his party, the election results also weakened MHP, as the party lost two of its largest municipalities (Adana and Mersin) and failed to knock out iYi Parti from the political arena.

CHP's victory in major cities revitalised the opposition by offering them a path for success against Erdoğan and revealed the weaknesses of Turkey's competitive authoritarian regime. Despite the uneven playing field, the opposition parties still had room to campaign, followed a coordinated strategy, and were able to win elections when they offered a positive agenda and popular candidates. Although it is too early to treat the 2019 local elections as what Howard and Roessler (2006) call a 'liberalising electoral outcome', the authoritarian regime has lost crucial 
resources in the midst of an economic recession. Opposition mayors can now use their office to appeal to a large part of the electorate, generate support for their parties, and undermine AKP's clientelist networks that sustained the ruling party's wide base at the local level. Here it is worth noting that Kemahlioğlu and Özdemir (2018) found that in national elections, AKP won more votes in metropolitan areas under its control than those under opposition control. In the near future, we could expect to observe a similar advantage emerging for CHP at the local level.

Municipal governments could thus serve as an alternative platform for the opposition to level the playing field and reduce AKP's disproportionate access to public and private resources. Should the opposition mayors perform well in their current term, the opposition bloc could pose a serious challenge to Erdoğan and his party in the general elections scheduled for 2023. Of course, his declining popularity may push him to become more authoritarian by eroding the competitive aspects of Turkey's political system. Erdoğan has already taken steps to curtail the power of elected mayors by transferring their authority in urban development and management of municipal companies to the central government. More importantly, the government recently displaced elected HDP mayors in three metropolitan areas and in several districts without due process. In the meantime, President Erdoğan has occasionally and covertly threatened CHP mayors, İmamoğlu in particular, with a similar measure. Hence, the impact of the local elections on AKP's competitive authoritarian regime is yet to be seen: it could ignite an authoritarian backlash or trigger redemocratisation. As was the case in the re-run in İstanbul, the will of the Turkish people will determine the outcome.

\section{Notes}

1. We thank Orçun Selçuk for this insight.

2. Each province is divided into districts (ilçe) and subdistricts (belde).

3. Meral Akşener, as a seasoned politician of a centre-right and nationalist background, had served as the interior minister for a brief period in the 1990s and joined the nationalist MHP in the 2000s. She headed the intra-party opposition within MHP against Devlet Bahçeli, whom Erdoğan co-opted after 2015. In response, Akşener tried to convene the party congress yet failed thanks to AKP's tinkering in favour of Bahçeli. As a result, she left MHP to establish her own party in 2017.

4. For a thorough discussion of the content and origins of the 'Turkish-Islamic synthesis' see Toprak (1990).

5. FETÖ (Fethullahçı Terör Örgütü - Fethullahist Terror Organisation) refers to the Hizmet movement of US-based preacher Fethullah Gülen, who is accused by Turkish authorities of orchestrating the coup attempt in July 2016. The PKK (Partiya Karkaren Kurdistan - Kurdistan Workers Party), founded by Abdullah Öcalan in 1978, has launched an insurgency against the Turkish state in 1984 and the conflict, costing more than 30,000 lives, is yet to be resolved.

6. For an English translation of the book, see http://dijitalmecmua.chp.org.tr/CHPRadikal \%20SevgiKitabiEng.pdf.

7. For the video see https://www.youtube.com/watch?v=JJKbRZwSb-U. 
8. DBP emerged in 2014 following a restructuring of the pro-Kurdish Peace and Democracy Party (Barış ve Demokrasi Partisi, BDP) into two branches. While the BDP parliamentary caucus joined the newly formed HDP which sought to appeal to both Turkish and Kurdish voters in the western provinces, the local chapters in the eastern provinces joined DBP.

9. Per legal statutes, parties could not object to voters' lists or the formation of ballot boxes after the elections. The only exception concerns the case of those citizens who vote in the elections despite being restricted by legal provisions. The YSK had rejected numerous objections in the past based on these provisions; yet, it agreed to accommodate most of AKP's requests in violation of the law and its own former rulings.

\section{Acknowledgments}

The authors would like to thank Yuksel Yasemin Altintas and Isabella Antunez De Mayolo Mauceri for their invaluable research assistance and Susannah Verney, Anna Bosco and the journal's two anonymous referees for their comments and suggestions.

\section{Disclosure statement}

No potential conflict of interest was reported by the authors.

\section{Notes on contributors}

Berk Esen is assistant professor of international relations at Bilkent University. Before joining Bilkent, he received his PhD in Government from Cornell University. His research focuses on the political economy of development, democratisation, and political parties, with a regional focus on Latin America and the Middle East. His solo and co-authored articles have appeared in Journal of Democracy, Third World Quarterly, and Turkish Studies.

Sebnem Gumuscu is assistant professor of political science at Middlebury College and the coauthor (with E. Fuat Keyman) of Democracy, Identity, and Foreign Policy in Turkey: Hegemony Through Transformation (2014). Her current book project focuses on democratic commitments of Islamist parties in power and her research has appeared in various journals including Comparative Political Studies, Journal of Democracy, Third World Quarterly, and Government and Opposition.

\section{References}

AK Parti. (2019a) 'Kampanya Kimliği' [Campaign identity], available online at: https://www. akadaylar.com/kampanya-kimligi-safha-2.html\#p62

AK Parti. (2019b) 'Manifesto' [Electoral Platform], available online at: https://akadaylar.com/ Manifesto_280cak2019.pdf

Ark-Yıldırım, C. (2017) 'Political parties and grassroots clientelist strategies in urban Turkey: one neighbourhood at a time', South European Society and Politics, vol. 22, no. 4, pp. 473-490.

Aydın-Düzgit, S. \& Balta, E. (2018) 'When elites polarise over polarisation: framing the polarisation debate in Turkey', New Perspectives on Turkey, vol. 560, pp. 153-176. 
Bayraktar, U. S. \& Altan, C. (2013) 'Explaining Turkish party centralism: traditions and trends in the exclusion of local party offices in Mersin and beyond', in Negotiating Political Power in Turkey: Breaking up the Party, eds E. Massicard \& N. F. Watts, Routledge, London, pp. 17-36. BBC Türkçe. (2019a) 'Yerel Seçim: siyasi partilerin aday listeleri nasıl şekillendi' [Local elections: Parties' lists of nominees], 19 February. available online at: https://www.bbc.com/turkce/ haberler-turkiye-47296568

BBC Türkçe. (2019b) 'İstanbul seçimi - Pontus tartışması 23 Haziran'da sonucu etkiler mi?' [İstanbul election: can the Pontus debate influence], 13 June. available online at: https:// www.bbc.com/turkce/haberler-dunya-48621611

Bianet. (2019) 'Everything you need to know about Turkey's 2019 local elections', 25 March. available online at: https://Bianet.org/english/diger/206574-everything-you-need-to-know -about-turkey-s-2019-local-elections

BloombergHT. (2019) 'TCMB: gıda enflasyonu taze sebze meyve fiyatlarındaki artışa bağlı olarak yükseldi' [Turkish Central bank: Fresh produce prices increased the inflation], 4 April. available online at: https://www.bloomberght.com/tcmb-cekirdek-gostergeler-ana-egilimi -dusuk-seviyeleri-korundu-2209861

Çalışkan, K. (2018) 'Toward a new political regime in Turkey: from competitive toward full authoritarianism', New Perspectives on Turkey, vol. 58, pp. 5-33.

Çarkoğlu, A. (2008) "Ideology or economic pragmatism?: profiling Turkish voters in 2007", Turkish Studies, vol. 9, no. 2, pp. 317-344.

Ciddi, S. \& Esen, B. (2014) 'Turkey's Republican People's Party: politics of opposition under a dominant party system', Turkish Studies, vol. 15, no. 3, pp. 419-441.

CNNTürk. (2019) 'CHP ve IYi Parti Ittifakının detayları belli oldu' [the details of the CHP-iYi Party alliance gets clear], 25 January. available online at: https://www.cnnturk.com/turkiye/kilic daroglu-ve-aksenerden-ortak-aciklama

DW. (2019) 'IBB eski yönetimi Erdoğan'a yakın vakıflara ne kadar yardım yaptı?' [How much did the former Municipal government donate to pro-Erdoğan foundations?], 19 April. available online at: https://www.dw.com/tr/ibb-eski-yönetimi-erdoğana-yakın-vakıflara-ne -kadar-para-yardımı-yaptı/a-48397744

Eligür, B. (2010) The Mobilization of Political Islam in Turkey, Cambridge University Press, Cambridge.

Ercan, H. (2019) 'Is hope more precious than victory? The failed peace process and urban warfare in the Kurdish Region of Turkey', South Atlantic Quarterly, vol. 118, no. 1, pp. 111-127.

Erdoğan, E. (2016) 'Turkiye'de Kutuplaşmanın Boyutları Araştırması', available online at: http:// kssd.org/site/dl/uploads/Kutuplaşma-Araştırması-Sonuçları.pdf

Esen, B. \& Gumuscu, S. (2016) 'Rising competitive authoritarianism in Turkey', Third World Quarterly, vol. 37, no. 9, pp. 1581-1606.

Esen, B. \& Gumuscu, S. (2017a) 'Turkey: how the coup failed', Journal of Democracy, vol. 28, no. 1, pp. 59-73.

Esen, B. \& Gumuscu, S. (2018a) 'Building a competitive authoritarian regime: state-business relations in the AKP's Turkey', Journal of Balkan and near Eastern Studies, vol. 20, no. 4, pp. 349-372.

Esen, B. \& Gumuscu, S. (2018b) 'The perils of Turkish presidentialism', Review of Middle East Studies, vol. 52, no. 1, pp. 43-53.

Esen, B. \& Gumuscu, S. (2017b) "A small yes for presidentialism: the Turkish constitutional referendum of April 2017", South European Society and Politics, vol. 22, no. 3, pp. 303-326.

Esen, B. \& Yardimci-Geyikçi, Ş. (2019) 'The Turkish presidential elections of 24 June 2018', Mediterranean Politics. doi:10.1080/13629395.2019.1619912 
Euronews. (2019a) 'Turkish opposition turns to radical love to smother Erdoğan', available online at: https://www.euronews.com/2019/04/24/turkish-opposition-turns-to-radical-love -to-battle-Erdogan

Euronews. (2019b) '23 haziran seçimlerinde yurttaş insiyatifleri' [Civic initiatives in June 23 election], 22 June. available online at: https://tr.euronews.com/2019/06/22/23-haziransecimlerinde-gonulluler-neden-organize-oldular

Fisunoğlu, A. \& Sert, D. Ş. (2019) 'Refugees and elections: the effects of Syrians on voting behavior in Turkey', International Migration, vol. 57, no. 2, pp. 298-312.

GazeteDuvar. (2019) 'CHP'de 18 saatlik toplantının perde arkası' [The Background Story of the 18-hour long meeting in the CHP], 28 January. available online at: https://www.gazetedu var.com.tr/politika/2019/01/29/chpde-18-saatlik-toplantinin-perde-arkasi/

Gidengil, E. \& Karakoç, E. (2016) 'Which matters more in the electoral success of Islamist (successor) parties-religion or performance? The Turkish case', Party Politics, vol. 22, no. 3, pp. 325-338.

Grigoriadis, I. N. (2016) 'The Peoples' Democratic Party (HDP) and the 2015 elections', Turkish Studies, vol. 17, no. 1, pp. 39-46.

Gumuscu, S. (2013) 'The emerging predominant party system in Turkey', Government and Opposition, vol. 48, no. 2, pp. 223-244.

Gumuscu, S. (2019) 'In Turkey, the latest elections had over 80 percent voter turnout. Here is why', The Washington Post, 30 June. available online at: https://www.washingtonpost.com/ politics/2019/06/30/turkey-latest-elections-had-over-percent-voter-turnout-heres-why/

Howard, M. M. \& Roessler, P. G. (2006) 'Liberalizing electoral outcomes in competitive authoritarian regimes', American Journal of Political Science, vol. 50, no. 2, pp. 365-381.

Hürriyet. (2019) 'Son dakika: cumhur ittifakı genişliyor' [People's alliance expands], 19 February. available online at: http://www.hurriyet.com.tr/gundem/son-dakika-cumhurittifaki-genisliyor-4-il-mhpye-17-il-ak-partiye-41122630

Independent Turkish. (2019) 'Istanbul, Yeşilli, ve Mustafakemalpaşa: YSK'dan üç itirazda iki farklı karar' [Two different YSK decisions in three objections: Istanbul, Yeşilli and Mustafakemalpasa], 9 May. available online at: https://www.independentturkish.com/ node/29506/haber/istanbul-ye\%C5\%9Filli-ve-mustafa-kemal-pa\%C5\%9Fa-yskdan-\%C3\% BC\%C3\%A7-itirazda-iki-farkl\%C4\%B1-karar

IYi Parti. (2019) 'Manifesto' [Electoral Platform], available online at: https://iyiparti.org.tr/ Assets/KurumsalKimlik/YerelSecim/iyiparti2019manifesto.pdf

Kalaycıoğlu, E. (2015) 'Turkish popular presidential elections: deepening legitimacy issues and looming regime change', South European Society and Politics, vol. 20, no. 2, pp. 157-179.

Karar. (2019a) 'Liderlerin seçim mesaisi' [Leaders' campaign traffic], March 29. available online at: https://www.karar.com/secim-2019/liderlerin-secim-mesaisi-1164919

Kemahlıoğlu, Ö. (2015) 'Winds of change? The June 2015 parliamentary election in Turkey', South European Society and Politics, vol. 20, no. 4, pp. 445-464.

Kemahlioğlu, Ö. \& Özdemir, E. (2018) 'Municipal control as incumbency advantage: an analysis of the AKP era', in Party Politics in Turkey, eds S. Sayarı, P. Ayan-Musil \& Ö. Demirkol, Routledge, London, pp. 116-135.

Konda. (2016) 'Suriyeli Sığınmacılara Bakış' [Perceptions towards Syrian refugees], available online at: http://konda.com.tr/tr/rapor/suriyeli-siginmacilara-bakis/

Konda. (2019a) '31 Mart Yerel Seçimlerinin Sayısal Analizi' [The Numerical Analysis of the March 31 Election], available online at: https://konda.com.tr/wp-content/uploads/2019/05/ 1904Nisan_Barometre_97_Kamuoyu.pdf

Konda. (2019b) '23 Haziran 2019 Sandık Analizi ve Seçmen Profilleri' [23 June 2019 Electoral Analysis and Voters' Profile], available online at: http://konda.com.tr/tr/rapor/23-haziran -2019-sandik-analizi-ve-secmen-profilleri/ 
Martin, N. (2018) 'The AK Party and the Kurds since 2014: a discourse of terror', British Journal of Middle Eastern Studies, vol. 45, no. 4, pp. 543-558.

McCoy, J., Rahman, T. \& Somer, M. (2018) 'Polarization and the global crisis of democracy: common patterns, dynamics, and pernicious consequences for democratic polities', American Behavioral Scientist, vol. 62, no. 1, pp. 16-42.

NTV. (2019a) 'Ankara'da cumhur ittifakı mitingi' [People's Alliance rally in Ankara], 23 March. available online at: https://www.ntv.com.tr/turkiye/ankarada-cumhur-ittifaki-mitingi, MZbw3a7BnOaHxL4-Bpcldg

Öniş, Z. (2015) 'Monopolising the centre: the AKP and the uncertain path of Turkish democracy', The International Spectator, vol. 50, no. 2, pp. 22-41.

Öniş, Z. (2016) 'Turkey's two elections: the AKP comes back', Journal of Democracy, vol. 27, no. 2, pp. 141-154.

Sabah. (2019) 'Liderler yerel seçim için yoğun mesai harcadı' [Leaders engaged in a packed schedule], 28 March. available online at: https://www.sabah.com.tr/gundem/2019/03/29/ liderler-yerel-secim-icin-yogun-mesai-harcadi

Sayarı, S. (2014) 'Interdisciplinary approaches to political clientelism and patronage in Turkey', Turkish Studies, vol. 15, no. 4, pp. 655-670.

Sayarı, S. (2016) 'Back to a predominant party system: the November 2015 snap election in Turkey', South European Society and Politics, vol. 21, no. 2, pp. 263-280.

T24. (2018) 'iYi Parti'nin 'Millet İttifakı sona erdi' açıklamasına CHP'den ilk yorum' [CHP's comments on IYi Party's decision to end the alliance], 4 July. available online at: https://t24.com. tr/haber/IYi-partinin-millet-ittifaki-sona-erdi-aciklamasina-chpden-ilk-yorum,667113

T24. (2019) 'Erdoğan: Öcalan ve Demirtaş arasında iktidar savaşı var' [Erdoğan: There is a tug of war between Öcalan and Demirtaş], 20 June. available online at: https://t24.com.tr/ haber/erdogan-ocalan-ve-demirtas-arasinda-iktidar-savasi-var,826988

Takvim. (2019) '50 günde 102 miting yapan Erdoğan, kapanışı İstanbul'da yaptı' [Erdoğan, who held 102 rallies in 50 days, ends his campaign in Istanbul], 30 March. available online at: https://www.takvim.com.tr/guncel/2019/03/30/50-gunde-102-miting-yapan-Erdogankapanisi-istanbulda-yapti

Toprak, B. (1990) 'Religion as state ideology in a secular setting: the Turkish-Islamic synthesis', in Aspects of Religion in Secular Turkey, ed. M. Wagstaff, University of Durham, Occasional Paper Series, no.40, pp. 10-15.

Tuğal, C. (2016) 'In Turkey, the regime slides from soft to hard totalitarianism', Open Democracy, 17 February. available online at: https://www.opendemocracy.net/en/turkeyhard-totalitarianism-erdogan-authoritarian/

Yeni Şafak. (2019) 'Işsizlik rakamları açıklandı' [Unemployment figures released], 17 June. available online at: https://www.yenisafak.com/ekonomi/issizlik-rakamlari-aciklandi-mart -2019-issizlik-verileri-3495153

Yeniçağ. (2018) 'Millet ittifakı sona erdi' [Nation's alliance ends], available online at: https:// www.yenicaggazetesi.com.tr/millet-ittifaki-sona-erdi-197453h.htm

Yeniçağ. (2019) 'Iğdır'ı HDP'ye teslim etmemek için aday göstermiyoruz' [We don't want the HDP to take Iğdır, so we don't have a nominee], 4 July. available online at: https://www. yenicaggazetesi.com.tr/igdiri-hdpye-teslim-etmemek-icin-aday-gostermiyoruz-222002h. htm

Yörük, E. (2012) 'Welfare provision as political containment: the politics of social assistance and the Kurdish conflict in Turkey', Politics \& Society, vol. 40, no. 4, pp. 517-547.

YSK. (2019) 'Election results', available online at: https://sonuc.ysk.gov.tr/sorgu 